\title{
CORPORATE SOCIAL RESPONSIBILITY APPLICATION AND ITS EFFECT ON IMAGES AND TRUST IN PT. ANGKASA PURA I BANDAR UDARA I GUSTI NGURAH RAI
}

\author{
Marthias Dian, Budhi Made Kembar Sri \\ Faculty of Economics and Business, University of Udayana, Bali, Indonesia \\ *E-mail: marthias.dinar@gmail.com
}

\begin{abstract}
The Aerospace Business developed rapidly in this long time. If the airport service company asked for its assistance to continue for a long period of time to grow the image and trust in the company, it must always service customers' needs to the community and society in general and support economic activities and economic development and empowering and developing economic needs as well as the social conditions of the community. This form of corporate responsibility can be done with the concept of Corporate Social Responsibility (CSR). This research relates to the understanding of CSR to Corporate Image, CSR to Trust, Image to Trust and CSR to Trust through Image. The object of this research is PT. Angkasa Pura I (Persero) I Gusti Ngurah Rai International Airport, Bali. The data source used consists of primary data and secondary data. Primary data obtained through airport user questionnaires and secondary data obtained by PT. Angkasa Pura I (Persero) I Gusti Ngurah Rai International Airport Bali and BPS. The data analysis technique used is quantitative analysis using the Structural Equation Model (SEM) model with the AMOS program. The research conducted has a significant influence on the implementation of CSR on the Company's Image and Trust, and the Corporate Image mediates the effect of CSR on Trust in the Company. The CSR program gives companies access to contribute to the community to surrounding companies, and at the same time will create a positive relationship with the company in the eyes of stakeholders.
\end{abstract}

\section{KEY WORDS}

Corporate social responsibility, trust, stakeholders, Bali.

The development of the business world in Indonesia has not been balanced with improving the level of public welfare and the environment. The development of the business world has not been able to contribute significantly to improving the quality of people's lives. Business activities are expected to hold on to social awareness that contributes and forms real care for the health of the community and helps maintain the environment. The contribution of the form of care and responsibility in the broad sense in question is to use the concept of Corporate Social Responsibility (CSR). Corporate Social Responsibility or commonly known as Corporate Social Responsibility (CSR) is an issue that has been developing for a long time. As is known that parties with interests in the company can be grouped into two, namely internal parties and external parties of the company. As is known, internal companies (management) tend to only think of the profits generated from their business without considering the impact that will be received by external companies in this case consumers and the environment for the company's operations. As part of being integrated with the concept of sustainable development, CSR requires recognition of the right of human beings to live side by side with the various resources that nature has provided.

CSR is a form of corporate responsibility towards its environment for social care and environmental responsibility by not ignoring the capabilities of the company. The implementation of CSR will have an impact on the sustainability of the company. A company in carrying out its activities must base its decisions not only based on mere financial factors such as profits or dividends, but also must base on social consequences in the environment for now and long term. Through CSR, the company frees itself from its goal of only seeking profit by expanding management's responsibility that the company not only has economic responsibility, but also other responsibilities for social life beyond its main obligations. CSR is 
not only related to social costs, coercion from the environment, or charitable activities, but also can be a source of opportunity, innovation and competitive advantage. In microeconomics studied the behavior of consumers and companies and the determination of market prices and the quantity of input factors, goods and services that are traded (Sukirno, 2005). Consumers are economic actors who carry out consumption activities. Where they buy or use a product either goods or services. In carrying out activities or activities will certainly appear about the behavior he did, this behavior is better known as consumer behavior. Consumer behavior is a process carried out by a person or organization in the form of activities to find, buy, use, enjoy, evaluate and release products that they have used or enjoyed (consumed) to carry out consumption activities to meet their needs

PT. Angkasa Pura I (Persero) as one of the State-Owned Enterprises (BUMN) always strives to improve the image and trust in the company. The efforts that have been made by the company include through assessments such as the assessment of service quality by Airport Council International, the assessment of clean toilets by the Indonesian Toilet Association, the assessment of the Airport by Bandara Majalah. Besides this, the efforts made by the company are through international standardization of the International Organization for Standardization (ISO) ISO 9001 Quality Management System and ISO 14001 Environmental Management System, 18001 Occupational Health and Safety Assessment Series (OHSAS), and Occupational Health Safety Management System ( SMK3) by the Ministry of Manpower. As well as other efforts made by the company are through audits conducted by international institutions, namely Safety Excellence and Security Excellence by the Airport Council International, Security Compliance by the United States Transportation Security Administration (TSA) and the Office of Transport Security (OTS).

The latest picture of image and trust in PT. Angkasa Pura I I Gusti Ngurah Rai Airport Bali can be seen from several survey results on services and certifications issued by several independent institutions related to products or services produced by airports. Most prominent in the survey of service results of the assessment by the Airport Council International $(\mathrm{ACl})$ which is an International Airport Organization, in a survey by $\mathrm{ACl}$ that I Gusti Ngurah Rai Airport - Bali is one of the best airports in the world, namely the Number Airport 3 in the World in 2015 and 2016. Besides the survey by ACI, PT. Angkasa Pura I I Gusti Ngurah Rai Airport - Bali received a service survey from several other institutions such as the Indonesian National Air Carries Association or the Association of Indonesian Aviation Companies with a 4.53 rating score from the scoring parameters 1-5 Likert scale and 3 Stars Airport by the agency which is quite prestigious in the aviation world namely Skytrax, which is the best result in Southeast Asia from other airports assessed by Skytrax.

In addition to service surveys by institutions both national and international, PT. Angkasa Pura I I Gusti Ngurah Rai Airport - Bali also obtained the certification of the International Organization for Standardization (ISO), namely ISO 9001 concerning Quality Management Systems and ISO 14001 concerning Environmental Management Systems. Related to ISO 14001 certification regarding Environmental Management Systems, I Gusti Ngurah Rai Airport - Bali is the pioneer and the only Airport in Indonesia that has received this certification.

According to Untung (2008), CSR is used to raise the image of the company to get social recognition in carrying out company activities and managing businesses by conducting social activities, expanding business opportunities carried out by the company and can be used to improve relations between stakeholders, employees and the company. And according to Kotler and Lee (2005), CSR that is implemented appropriately, both in the fields of economy, social and environment, will be able to provide many benefits for the company, one of which is being able to improve Corporate Image. If the company carries out its CSR program thoroughly, consumers will have a positive association with the company's CSR program, this association significantly influences their attitude towards the company and can improve the company's image (Lu et al, 2015). Kazi and Chouthoy (2016) in his research journal "En route to a Theory - Building Consumer Brand Commitment through CSR Reputation" suggests that philanthropic actions that are part of CSR will help in building trust. 
Satisfying consumers is a difficult thing before gaining their trust, so trust affects customer satisfaction. A consumer who trusts an entity or brand will be satisfied and committed to it.

PT. Angkasa Pura I (Persero) as one of the State-Owned Enterprises (BUMN) has carried out the activities of the Partnership and Community Development Program since 1992, as the Development of Small Business and Cooperatives (PUKK). The company's CSR program aims to encourage people's economic activities and growth, as well as empower and develop economic conditions and social conditions of the community. This is also in line with the company's recent missions, including: Becoming a government partner and economic growth driver, and making a positive contribution to the environment. Furthermore, the organization of the Partnership and Community Development Program unit is based on the determination of the Organization and Work Procedure of PT. Angkasa Pura I (Persero) has since changed into a Corporate Social Responsibility (CSR) unit.

This is also regulated, among others, in the SOE Minister's Regulation Number: PER09 / MBU / 07/2015 concerning the State-Owned Enterprise Partnership Program and Community Development Program. The regulation states that the BUMN Partnership Program - which is one form of CSR program - is a program to improve the ability of small businesses to become resilient and independent. And the Community Development Program, hereinafter referred to as the BL Program, is an empowerment program for community social conditions by BUMN.

The CSR unit at the Head Office is part of a work unit led by a Head of CSR and is carried out directly by the CSR Department led by a CSR Cooperation Department Head and Corporate Social Environment Department Head. As for the Branch Office, the CSR unit is part of a work unit led by a Sales Department Head, whose implementation is the main activity of the CSR Section Head. The main activities of the Partnership and Community Development Program conducted by PT. Angkasa Pura I (Persero) in both the Head Office and Branch Offices includes the activities of Loan Fund Distribution, Guidance (Education, promotion / exhibition), Provision of Community Development Assistance Funds, and Monitoring of business activities of Patronage Partners. The amount of Corporate Social Responsibility funds that have been channeled by PT. Angkasa Pura I (Persero) I Gusti Ngurah Rai Airport - Bali can be seen in the table below.

Table 1 - Amount of Funds Distribution Corporate Social Responsibility, PT. Angkasa Pura I (Persero) I Gusti Ngurah Rai Airport - Bali

\begin{tabular}{ccc}
\hline Year & Partnership Program (Rp) & Community Development Program (Rp) \\
\hline 2013 & $1,990,000,000$ & $752,600,105$ \\
2014 & $2,570,000,000$ & $1,026,693,221$ \\
2015 & $4,000,000,000$ & $736,789,900$ \\
2016 & $3,405,000,000$ & $1,493,995,461$ \\
\hline
\end{tabular}

Source: PT. Angkasa Pura I (Persero) I Gusti Ngurah Rai Airport-Bali, 2017.

With this research, it can be seen the implementation or implementation of CSR and how much the relationship of CSR to shape the image and trust in the company, namely PT. Angkasa Pura I (Persero) I Gusti Ngurah Rai - Bali Airport Branch Office by the author.

\section{LITERATURE REVIEW}

State-Owned Enterprises are entities owned by the state. Definition of State-Owned Enterprises is a business entity whereby all or part of its capital is owned by the state through direct participation derived from separated state assets (Based on Law of the Republic of Indonesia No. 19 of 2003). According to Darmadjati (2001) the notion of airlines or airlines is a company that is either privately owned or government that specifically serves both scheduled and unscheduled air transport. According to Suharno (2009) Airports are airports that are used for landing and taking off airplanes, boarding passengers and loading and unloading cargo and posts, which are equipped with flight safety facilities and as a place of intermodal transportation. CSR is a form of corporate responsibility towards its environment 
for social care and environmental responsibility by not ignoring the capabilities of the company. Solomon (2011), states that consumer satisfaction is an overall feeling of consumers about products or services that have been purchased by consumers. According to Bill Canton in Soemirat \& Ardianto (2007) the image is the impression, feeling, picture of the public towards the company; the impression that was intentionally created from an object, person or organization.

\section{RESEARCH HYPOTHESES}

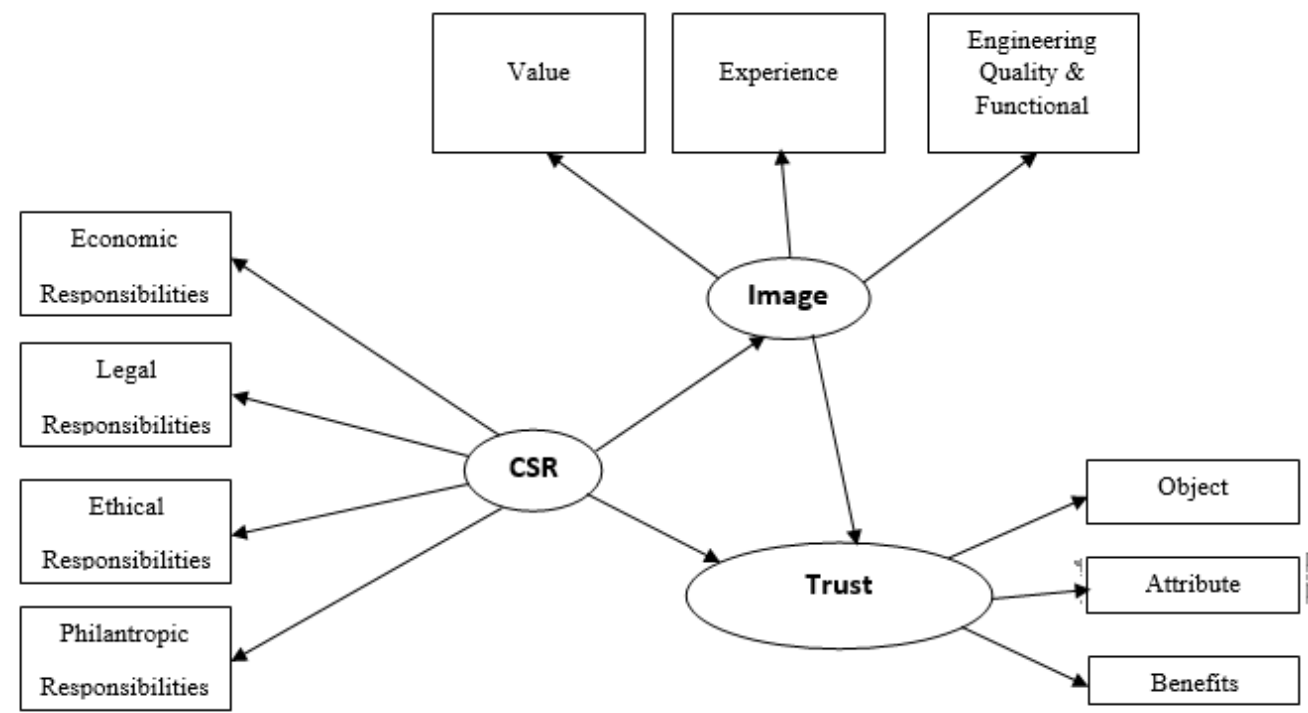

Figure 1 - Thinking Framework

From the literature review and research conceptual framework the following hypotheses are formulated:

- Corporate Social Responsibility (CSR) has a positive and significant effect on the image of PT. Angkasa Pura I (Persero) I Gusti Ngurah Rai Airport Branch Office Bali;

- Corporate Social Responsibility (CSR) and Image have a positive and significant effect on trust in PT. Angkasa Pura I (Persero) I Gusti Ngurah Rai Airport Branch Office - Bali;

- Corporate Social Responsibility (CSR) indirectly influences trust through Citra at PT. Angkasa Pura I (Persero) I Gusti Ngurah Rai Airport Branch Office - Bali.

\section{METHODS OF RESEARCH}

This study uses a quantitative method using a questionnaire instrument. The questionnaire used is the result of adaptation from similar studies that have been done before. The questions are answered using a Likert Scale from 1 to 5 . Values indicate strongly disagree, value 2 indicates disagree, value 3 indicates doubt, value 4 indicates agree and value indicates strongly agree. The research was carried out in a representative population and specific sample of service users or passengers of I Gusti Ngurah Rai Airport. The study aims to obtain empirical evidence, test and explain the effect of CSR on Image and Trust in the company (PT Angkasa Pura I, I Gusti Ngurah Rai Airport Branch Office). The population in this study were service users of PT. Angkasa Pura I (Persero) International Airport Branch Office I Gusti Ngurah Rai, in this case is the average passenger departing domestic I Gusti Ngurah Rai Airport each month in 2016 totaling 414,851 people. This is as explained earlier that there are 2 groups or strata in the study sample, namely Full Service Airlines passengers and Low Cost Carrier passengers. While the determination of respondents in this 
study using non-probability sampling technique, namely convenience sampling technique (accidental sampling). This method is a sampling procedure that selects samples from people or units that are most easily found or accessed as respondents. Using covenience technique because it is based on the mobility of service users or passengers who are quite high. So the researcher will provide a questionnaire to passengers who can be found and willing to become respondents.

Table 2 - Sample Determination

\begin{tabular}{ccccc}
\hline Number & Types of Passenger Services & Total passenger & Percentage (\%) & Number of respondent \\
1 & Full Service Airline & 1.772 .581 & 35,61 & 64 \\
2 & Low Cost Carrier & 3.205 .631 & 64,39 & 114 \\
& Jumlah & 4.978 .212 & 100 & 178 \\
\hline
\end{tabular}

Source: PT. Angkasa Pura I (Persero) I Gusti Ngurah Rai Airport - Bali, 2017.

From the results of the sample calculation of 178 respondents, it will be divided into 2 (two), namely $36 \%$ of Full Service Airlines or as many as 64 respondents and $64 \%$ of Low Cost Carrier or as many as 114 respondents, in order to represent all types of passengers or airport service users.

\section{RESULTS OF STUDY}

This study uses quantitative analysis techniques using the SEM (Structural Equation Modeling) model or the Structural Equation Model with the AMOS program. The assumption of data normality is a test to find out whether the data has a normal distribution. If the value of the critical ratio (CR) of each variable for kurtosis (shunt) is greater than \pm 2.58 then the distribution is not normal univariate.

Table 3 - Evaluation of Full Model Data Normality

\begin{tabular}{|c|cccccc|}
\hline Variable & $\min$ & $\max$ & skew & CR & kurtosis & CR \\
\hline y1.1 & 2.500 & 5.000 & -.365 & -1.988 & -.104 & -.284 \\
y1.2 & 2.750 & 5.000 & -.187 & -1.021 & -.578 & -1.573 \\
y1.3 & 2.200 & 5.000 & -.500 & -2.724 & .540 & 1.472 \\
y2.3 & 2.000 & 5.000 & -.777 & -4.231 & .324 & .884 \\
y2.2 & 2.500 & 5.000 & -.421 & -2.295 & -.327 & -.890 \\
y2.1 & 2.670 & 5.000 & -.603 & -3.286 & -.013 & -.035 \\
x1 & 2.500 & 5.000 & -.355 & -1.933 & .071 & .194 \\
x2 & 2.500 & 5.000 & -.349 & -1.903 & -.288 & -.783 \\
x3 & 2.500 & 5.000 & -.302 & -1.646 & -.275 & -.750 \\
x4 & 2.600 & 5.000 & -.273 & -1.489 & -.608 & -1.657 \\
Multivariate & & & & & 29.033 & 12.502 \\
\hline
\end{tabular}

Source: Primary Data.

From the table it is found that the value of critical ratio $(C R)$ on all variables $x 1$ (Economic Responsibilities), x2 (Legal Responsibilities), x3 (Ethical Responsibilities), x4 (Philanthropic Responsibilities), y1.1 (Value), y1.2 (Experience), y1.3 (Technical \& Functional Quality), y2.1 (Object Trust), y2.2 (Attribute Trust), and y.2.3 (Benefit Trust) are normally distributed due to $\mathrm{CR}$ (shunt) value $< \pm 2.58$.

Outlier is an observation condition of a data that has unique characteristics that look different from other data observations and have extreme values in both single and combination variables. Identification of multivariate outliers is done by looking at the value of the mahalanobis distance. This test is conducted to assess the fairness or extreme data. Multivariate outlier detection was carried out based on the value of chi-squares with a degree of freedom $=32$, at a significance level of $p<0.05$. So the value of the mahalanobis distance 
$(32,0.05)=46,194$. Therefore if there are cases that have an expensive distance $>46,194$ is a multivariate outlier. Following are the multivariate outlier test results:

Table 4 - Result of Multivariate Outlier

\begin{tabular}{cccc}
\hline Observation number & Mahalanobis d-squared & p1 & p2 \\
\hline 18 & 49.469 & .000 & .000 \\
42 & 35.226 & .000 & .000 \\
80 & 33.518 & .000 & .000 \\
124 & 28.359 & .002 & .000 \\
147 & 27.773 & .002 & .000 \\
17 & 27.465 & .002 & .000 \\
170 & 26.045 & .004 & .000 \\
51 & 22.891 & .011 & .001 \\
22 & 22.683 & .012 & .000 \\
75 & 22.429 & .013 & .000 \\
\hline
\end{tabular}

Source: Primary Data (Top 10 data).

Based on the mahalanobis distance output from the AMOS program, 1 data was found, namely number 18 with a value of more than 46,194 . Because the amount of data can be said to be small ( 1 of 178 data) so that it can be concluded multivariate that there are no data outliers and data must be included in the subsequent analysis.

Multicollinearity evaluation can be seen from the determinant of sample covariance matrix, where values equal to 0 indicate multicollinearity in the data (Ferdinand, 2002). In this study the covariance matrix determinant of sample value was 0.000000083 which means $>0$, so it can be concluded that multicollinearity does not occur. This means that SEM assumptions are fully evaluated for multicollinearity.

Confirmatory analysis of exogenous variables in this study is Corporate Social Responsibility (CSR) with Economic Responsibilities (x1) indicators, Legal Responsibilities (x2), Ethical Responsibilities (x3) and Philantrophic Responsibilities (x4). The test results for exogenous variables are:

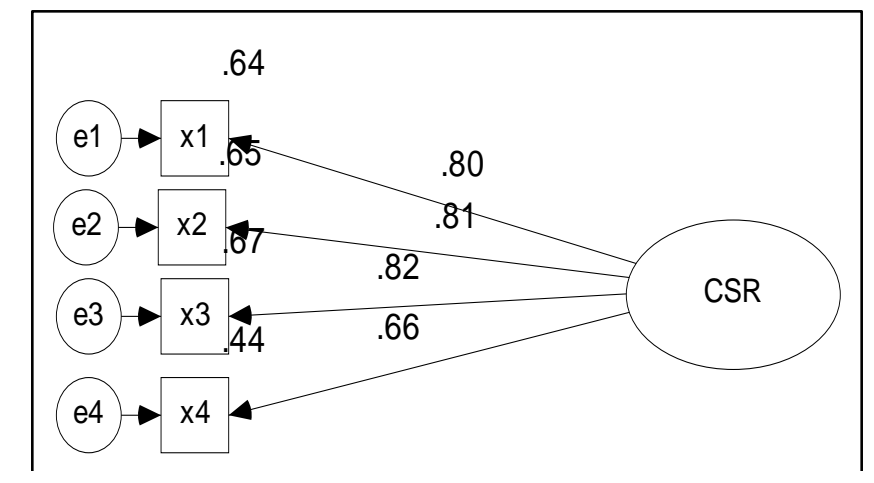

Figure 2 - Confirmatory Factor Analysis of CSR Variable

All indicators in the Corporate Social Responsibility (CSR) variable get a loading value $>0.50$ which is Economic Responsibilities $(x 1)=0.80$, Legal Responsibilities $(x 2)=$ 0.81 , Ethical Responsibilities $(x 3)=0.82$ and Philantrophic Responsibilities $(x 4)=0.66$ which indicate Model statistics are constructed from four variables explaining and defining exogenous constructs. From the four indicators according to the figure above, it can be seen that CSR in the form of Ethical Responsibilities (x3) with a loading value of 0.82 has the most influence on the CSR variable model builder.

The confirmatory analysis of endogenous variables in this study is the Image variable with the Value indicator (y1.1), Experience (y1.2), and Technical \& Functional Quality (y1.3), as well as the Trust variable with the Object Trust indicator (y.2.1), Attribute Trust (y.2.2) and Benefit Trust (y.2.3). Test results for Image endogenous variables are: 


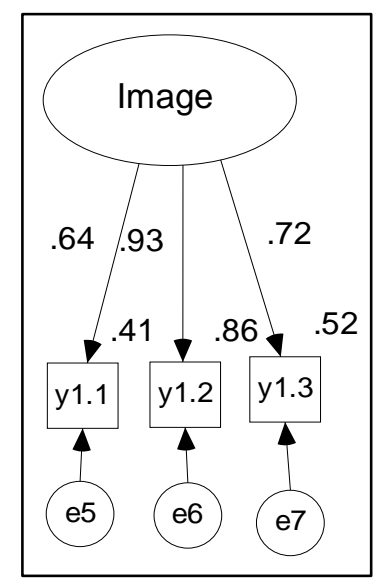

Figure 3 - Confirmatory Factor Analysis of Image Variable

From the image of the Confirmatory Factor Analysis Image Variables, it is known that all indicators in the Image variable get loading values $>0.50$, ie Value $(\mathrm{y} 1.1),=0.64$, Experience $(\mathrm{y} 1.2)=0.93$, and Technical \& Functional Quality $(\mathrm{y} 1.3)=0.72$, this result indicates statistically the model built from the three variables explaining and defining the image variable construct. From the three indicators according to the picture above it can be seen that according to Experience respondents (y1.3) with a loading value of 0.93 the most influential on the forming of the Citra variable model.

The confirmatory test results for the Trust endogenous variable are:

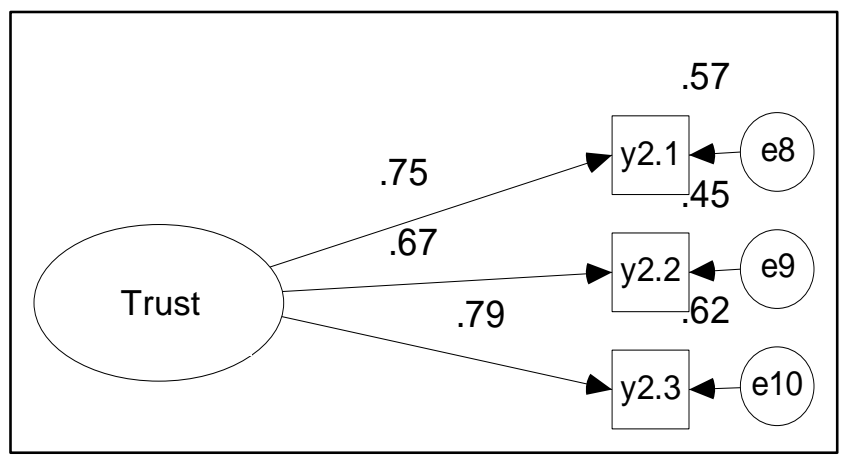

Figure 4 - Confirmatory Factor Analysis of Trust Variable

From the picture of Confirmatory Factor Analysis Variable Trust, it is known that all indicators in the Trust variable get a loading value $>0.50$, which is Object Trust $(y 2.1)=0.75$, Attribute Trust $(y 2.2)=0.67$, and Trust Benefits $(y 2.3)=0.79$, this result indicates that statistically the model is constructed from the three variables explaining and defining the construct of the Trust variable. From the three indicators according to the picture above, it can be seen that according to the respondents, the Benefits Trust (y2.3) with a loading value of 0.79 has the most influence on the Trust variable model builder.

After the Measurement Model was tested with Confirmatory Factor Analysis (CFA) and assumptions in the modeling of the Structural Equation Model (SEM) were met, the next step was analysis of the Full Structural Equation Model to determine the suitability of the model and causality built into the model. The results of data processing for analysis of the Full Structural Equation Model can be seen in the following figure 5.

To find out whether the model built statistically can be supported and in accordance with the specified fit model. Tests are carried out using several Goodness-of-fit Indices and cut-offs to test whether a model is acceptable or not. The results of processing data related to Goodness-of-fit Indices on the Full Structural Equation Model are as follows in table 5. 


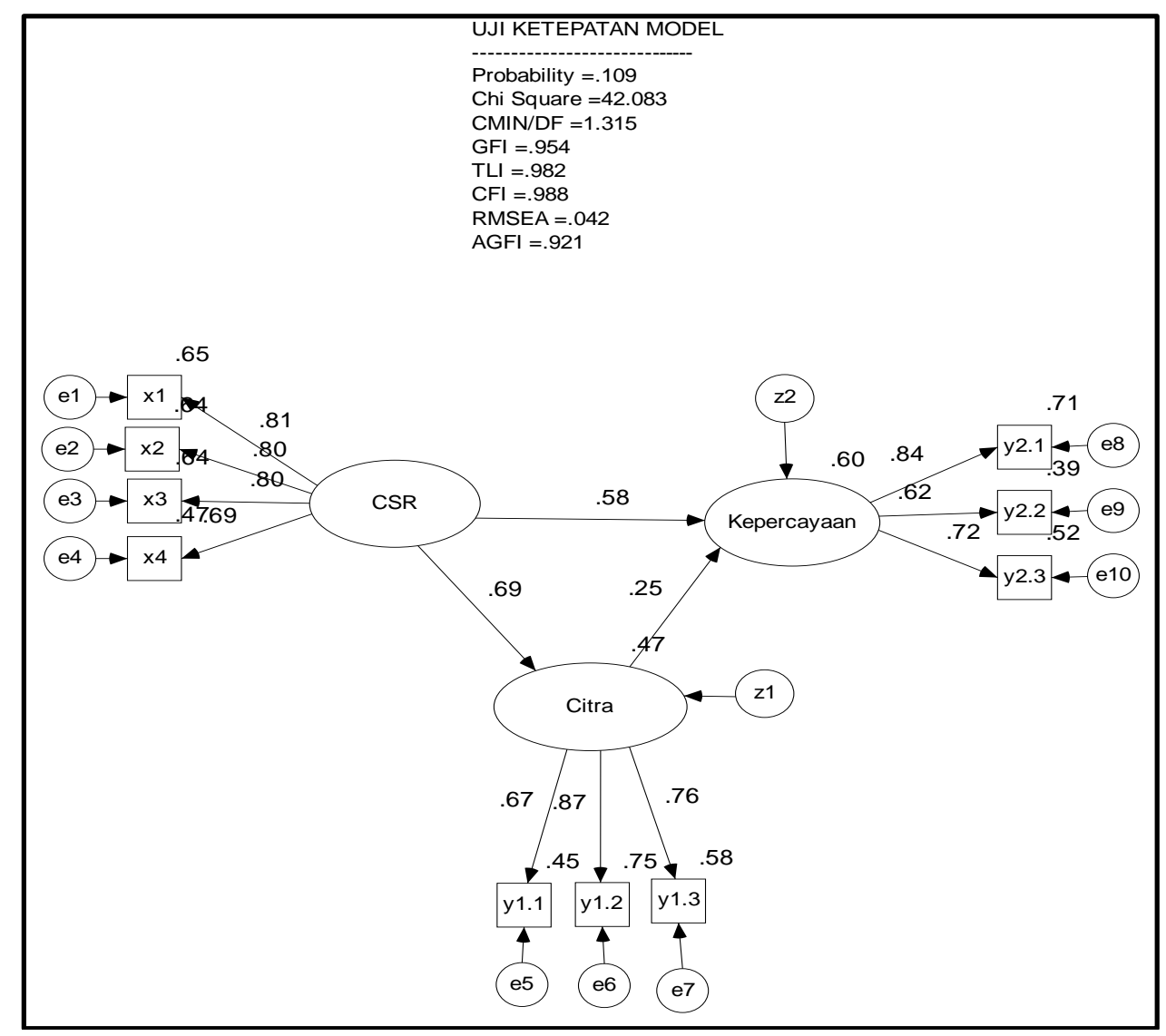

Figure 5 - Full Structural Equation Model Analysis

Table 5 - Goodness-of-fit Indices Variable Full Structural Equation Model

\begin{tabular}{cccc}
\hline Goodness-of-fit Indices & Cut-off Value & Model Result & Model Evaluation \\
\hline Chi-square & $\leq 46,19426^{*}$ & 42,083 & Baik \\
DF & Positive & 32 & Baik \\
Probability & $\geq 0,05$ & 0,109 & Baik \\
CMIN/DF & $\leq 2,00$ & 1,315 & Baik \\
RMSEA & $\leq 0,08$ & 0,042 & Baik \\
GFI & $\geq 0,90$ & 0,954 & Baik \\
TLI & $\geq 0,90$ & 0,982 & Baik \\
CFI & $\geq 0,90$ & 0,988 & Baik \\
AGFI & $\geq 0,90$ & 0,921 & Baik \\
\hline
\end{tabular}

Source: Primary Data, 2019.

Based on Table 5, the results of the overall model testing are in accordance with the Goodness-of-fit Indices criteria based on the required cut-off value. Thus for the Full Structural Model the research variables, namely CSR, Image and Trust can be accepted as forming a fit model.

Hypothesis testing of the relationship of quality between research variables is processed using AMOS. Hypothesis testing can be seen from the results of coefficients in the regression weight values listed in column C.R. and P. The value stated in column C.R. must be compared with the critical value of \pm 1.96 at the $5 \%$ significance level. If the value is C.R. greater than the critical value \pm 1.96 at the significance level $p<0.05$, the proposed hypothesis can be accepted, and vice versa if the value is C.R. smaller than the critical value \pm 1.96 at the significance level $p>0.05$, the proposed hypothesis is rejected. Regression Weight hypothesis testing is shown in the following Table 6.

Regression weight is used to determine the hypothesis significance between exogenous and endogenous variables. The CSR variable for the Image in the Table is obtained by the value C.R. 6,756 with $P<0.05$. Because the significance of $P$ in the Table is 
less than 0.05 , which is 0,000 , thus $\mathrm{Ho}$ is rejected and $\mathrm{Ha}$ is accepted. So it can be concluded that there is a significant relationship between CSR and Image.

Table 6 - Regression Weights

\begin{tabular}{cccccccc}
\hline & & & Estimate & S.E. & C.R. & P & Label \\
\hline Image & $<---$ & CSR & .666 & .099 & 6.756 & ${ }^{* * *}$ & par_7 \\
Trust & $<---$ & CSR & .684 & .151 & 4.515 & $* * *$ & par_6 \\
Trust & $<---$ & Image & .298 & .135 & 2.209 & .027 & par_9 \\
x1 & $<---$ & CSR & 1.012 & .108 & 9.361 & $* * *$ & par_1 \\
x4 & $<---$ & CSR & 1.000 & & & & \\
x3 & $<---$ & CSR & 1.062 & .116 & 9.188 & $* * *$ & par_2 \\
x2 & $<---$ & CSR & 1.036 & .111 & 9.361 & $* * *$ & par_3 \\
y2.3 & $<---$ & Trust & 1.000 & & & & \\
y2.2 & $<---$ & Trust & .748 & .098 & 7.660 & $* * *$ & par_4 \\
y2.1 & $<---$ & Trust & .995 & .112 & 8.913 & $* * *$ & par_5 \\
y1.3 & $<---$ & Image & 1.000 & & & & \\
y1.2 & $<---$ & Image & 1.127 & .109 & 10.381 & $* * *$ & par_8 \\
y1.1 & $<---$ & Image & .891 & .107 & 8.293 & $* * *$ & par_10 \\
\hline
\end{tabular}

CSR Variables towards Trust in the Table obtained C.R values. 4,515 with $P<0.05$. Because the significance of $P$ in the Table is less than 0.05 , which is 0,000 , thus $\mathrm{Ho}$ is rejected and $\mathrm{Ha}$ is accepted. So it can be concluded that there is a significant relationship between CSR and Trust. The Image Variables for Trust in the Table obtained the value C.R. 2,209 with $P<0.05$. Because the significance of $P$ in the Table is less than 0.05 , which is 0.027 , thus $\mathrm{Ho}$ is rejected and $\mathrm{Ha}$ is accepted. So it can be concluded that there is a significant relationship between Image and Trust.

\section{DISCUSSION OF RESULTS}

PT. Angkasa Pura I (Persero) I Gusti Ngurah Rai International Airport Branch Office Bali has been implementing CSR programs since 1992. The company's CSR program aims to encourage economic activity and growth. This is in line with several company missions, namely becoming a government partner and driving economic growth, and making a positive contribution to the environment. CSR activities carried out include distribution of loan funds, guidance (education, promotion / exhibition), provision of environmental assistance funds and monitoring of activities of assisted partners.

PT. Angkasa Pura I (Persero) International Airport Branch Office I Gusti Ngurah Rai Bali has implemented a CSR program on an ongoing basis starting in 1992, with the total Partnership Program funds being channeled to small businesses in the amount of Rp. $39,293,500,000$ (thirty nine billion two hundred ninety three million five hundred thousand rupiahs) and partnership funds channeled to cooperatives in the amount of Rp. $2,507,250,000$ (two billion five hundred seven million two hundred fifty thousand rupiahs), as well as the Community Development Program with total funds that have been distributed up to 2017 amounting to Rp. 10,536,316,322 (ten billion five hundred thirty six three hundred sixteen thousand three hundred twenty two rupiahs).

Distribution to fostered partners is done with the intention that the fostered partners can have additional capital to develop their business to become more advanced, broader market and stronger business, such as increasing production capacity and product marketing. Besides the distribution of funds from PT. Angkasa Pura I (Persero) I Gusti Ngurah Rai International Airport Bali also conducts training for MSMEs that aim to gain knowledge that can be applied to increase their respective businesses. In the Community Development Program the company channeled funds to repair religious facilities, public facilities and education, such as building a School Health Unit room, adding a collection of books to grow and increase reading interest (School Literacy Movement), providing tables and chairs in Adat Village around the airport. By looking at the total funds and programs that the company has carried out in implementing CSR, PT. Angkasa Pura I (Persero) I Gusti Ngurah Rai 
International Airport Branch Office Bali has been fully committed to running a CSR Program that aims to encourage activities and economic growth and contribute positively to the environment.

Based on Table 6 Regression Weight, it is found that the CSR variable has a direct effect on the Image of 0.666 with a p-value of less than 0.05 , which is 0,000 , so Ho is rejected and $\mathrm{Ha}$ is accepted. This shows that the better the implementation of Corporate Social Responsibility, the better the image obtained by the Company.

The positive influence of CSR on Corporate Image is in line with the theory put forward by Keraf (2000), which states that the benefits of applying responsibility and social involvement will create a positive image in the eyes of the public. Whereas according to Beekum in Mowen and Minor (2002) CSR can form a positive image of the company.

The results of this study are also in line with the previous research, which was revealed by Abdullah and Azis (2013) in their research that the implementation of CSR has a direct impact on the reputation or image of the company. In addition, according to Huang, et. al (2014) in their study revealed that CSR significantly had a positive effect on company image, service quality, and purchase intention, the corporation or company could improve the company's image with activeness in charity and social welfare activities.

Based on the results of testing the second hypothesis the results show that CSR variables have a direct effect on Trust of 0.684 with a p-value of less than 0.05 , which is 0,000 , thus $\mathrm{Ho}$ is rejected and $\mathrm{Ha}$ is accepted. So it can be concluded that there is a significant influence between CSR and Trust. This shows that the better the implementation of Corporate Social Responsibility, the better the Trust in the Company.

Airport is a service business sector that is airport services that are sensitive to Trust. Establishing trust can be realized with real actions of the company as a form of fulfilling the wishes and needs of the community (expectations) that are constantly developing, one of the real manifestations is the implementation of CSR. Trust of service users will be formed if the company can implement CSR properly, seriously, with quality, continuous, comprehensive in various aspects.

The results of this hypothesis test are in line with previous research, Kazi and Chouthoy (2016) revealed that philanthropic actions contained in CSR will help in forming trust in the company. Whereas Choi and La (2013) suggested that CSR has a positive impact on consumer trust through legal and ethical aspects in implementing CSR. Consumers who believe that companies that are committed to respecting consumer rights and voluntarily satisfying their needs will be easier to trust (Castaldo et.al, 2008).

On the results of the third hypothesis test results obtained that the Image variable directly affects the Trust of 0.298 with p-value less than 0.05 , which is 0.027 , so Ho is rejected and $\mathrm{Ha}$ is accepted. So it can be concluded that there is a positive and significant influence between Image and Trust. This shows the better the Corporate Image, the better the Trust in the Company.

Image and Trust are but cannot be physically reflected, because images and beliefs are in the mind. Even so, the image and trust can be known, measured and changed. When service users use services at the airport, one of the factors that will be considered is the issue of reputation or image, where the image is an important factor in shaping the trust of a person or service user to the company. If the company has a bad image and often has problems with service users, service users will feel lazy, uncomfortable and reduce their trust in the company. Vice versa, if the company has a good image, then service users will trust and be comfortable in using services or services provided or sold by the company.

The results of this hypothesis test are in line with previous research, that companies that have a positive image will reflect that the company has good and consistent service quality and has good reputation and credibility, therefore consumers will feel confident that the company will provide what they need and as the end result will lead to consumer confidence (Ariszani et. al, 2015). Whereas Fayumi \& Tjahjaningsih (2015) revealed that the higher the company's image, the higher the consumer trust. The company's image can be seen as an important publicity tool that tends to strengthen consumer confidence (Nguyen et al, 2013). 
Table 7 - Nilai Standardized Direct, Indirect and Total Effect

\begin{tabular}{llllll}
\hline & & & Direct Effect & Indirect Effect & Total Effect \\
\hline Image & $<---$ & CSR & .686 & - & .686 \\
Trust & $<---$ & CSR & .583 & .169 & .752 \\
Trust & $<---$ & Image & .246 & - & .246 \\
\hline
\end{tabular}

Based on Table 7 there is an indirect influence between Corporate Social Responsibility (CSR) on Trust mediated by the Image of 0.169 . This shows that the Corporate Image mediates the effect of CSR on Company Trust, or it can be interpreted that the Image has an indirect influence on the Corporate Social Responsibility (CSR) variable on Trust, that is by increasing the total effect of CSR on Trust.

\section{CONCLUSSION AND SUGGESTIONS}

Based on the results of discussion of research, it can be concluded as follows:

- CSR has a direct effect on the Image, which shows that the better the implementation of Corporate Social Responsibility, the better the image the Company can get;

- CSR has a direct effect on trust, this shows that the better the implementation of Corporate Social Responsibility, the better the Trust in the Company;

- The image has a direct effect on trust, so that the better the image of the company, the better the trust in the company;

- The Company's image mediates the effect of CSR on Trust in the Company, or it can also be interpreted that the Image has an indirect influence on the variable Corporate Social Responsibility (CSR) on Trust;

- Overall respondents 'assessment of the variables used in the research, namely Corporate Social Responsibility (CSR), Image and Trust can be described on the tabulation of the respondents' answers to getting good results. Of the three variables that get the lowest scores are: ethical responsibilities indicator for CSR variables, technical \& functional quality indicators for image variables and attribute trust indicators for trust variables.

After analyzing, discussing and drawing conclusions, the authors provide suggestions as considerations related to the results of the study. The suggestions that can be conveyed are that PT. Angkasa Pura I (Persero) I Gusti Ngurah Rai International Airport further augments monumental CSR programs or is more memorable to the wider community. So that it will increase the positive association of consumers or service users of the company's CSR program, this increase will affect attitudes towards the company and improve the company's image, and will help build trust in the company, and increase the dissemination of information about CSR programs that have been carried out by the company, or service users become more aware of the program, and conduct community need assessments or assessments of community needs, so that the CSR program undertaken becomes more targeted and useful. Improve indicators with the lowest value of respondents' assessment of each variable, namely increasing the company's ethical responsibilities for CSR variables by increasing compliance with applicable standards and norms. Improving technical \& functional quality on image variables and attribute trust in the trust variable through increasing the fulfillment of airport services to consumers.

This study has several limitations including:

- Need to do further research regarding the Implementation of Corporate Social Responsibility (CSR) at PT. Corporate Angkasa Pura I (Persero), namely all branch offices in the company, so as to obtain a complete picture of the implementation of CSR that has been carried out by the company and its impact on Image and Trust in the company;

- Research is conducted at certain times for service users who are constantly changing their type and character (dynamic), so that similar research needs to be done in the future to confirm and compare the results of research from several different times. 


\section{REFERENCES}

1. Abdullah, Zuhamri \& Yuhanis Abdul Azis. 2013. Institutionalizing Corporate Social Responsibility: Effects on corporate Reputation, Culture, and Legitimacy in Malaysia. Social Responsibility Journal, 9 (3): 344-361.

2. Arikan, E., D. Kantur, C. Maden \& E.E Telci. 2014. Investigating the Mediating Role of Corporate Reputation on the relationship Between Corporate Social Responsibility and Multiple Stakeholder Outcomes. Qual Quant Journal, 50: 129-149.

3. Ariszani, Merza, Suharyono \& Srikandi Kumadji. 2015. Pengaruh Citra Perusahaan terhadap Kepercayaan serta Dampaknya pada Minat Beli. Jurnal Adm. Bisnis, 3(1).

4. Beekum, Rafik Issa. 2004. Etika Bisnis Islami. Yogakarta: Pustaka Pelajar

5. Castaldo, S., F. Perini, N. Misani \& A. Tencati. 2008. The Missing Link Between Corporate Social Responsibility and Consumer Trust: The Case of Fair Trade Products. Journal of Business Ethics, 84(1): 1-15.

6. Choi, Beomjoon \& Suna La. 2013. The Impact of Corporate Social Responsibility (CSR) and Customer Trust on the Restoration of Loyalty After Service Failure and Recovery. Journal of Services, 223-233.

7. Fayumi, Ah. \& Endang Tjahjaningsih. 2015. Pengaruh Citra Perusahaan and Kepuasan terhadap Kepercayaan and Dampaknya pada Loyalitas. Kajian Multi Disiplin IImu untuk Mewujudkan Poros Maritim dalam Pembangunan Ekonomi Berbasis Kesehjateraan Rakyat.

8. Ferdinand, A. 2002. Structural Equation Model dalam Penelitian Manajemen. Semarang: BP Universitas Diponogoro.

9. Huang, Chun-Chen, Szu-Wei Yen, Pei-Chen Huang, Cheng Yi Liu. 2014. The Relationship among Corporate Social Responsibility, Service Quality, Corporate Image And Purchase Intention. The International Journal of Organizational Innovation, 6 (3): 6884.

10. Kazi, Roshan \& Supriya Choutoy. 2016. En route to a Theory - Building Consumer Brand Commitment through CSR Reputation. Global Business and Management Research: An International Journal (8) 3: 67-82.

11. Keraf, Sonny. 2000. Etika Bisnis Tuntutan and Relevansinya. Yogyakarta: Kanisius.

12. Kotler, Philip. 2005. Manajemen Pemasaran Jilid 1. Jakarta: Indeks.

13. Mowen, John.C \& Michael Minor. 2002. Perilaku Konsumen. Jakarta: Erlangga.

14. Nguyen, N., Andre Leclerc \& G. LeBlanc. 2013. The Mediating Role of Customer Trust on Customer Loyalty. Journal of Service Science and Management, 6: 96-109.

15. PT. Angkasa Pura I (Persero). 2017. Data Penumpang di Bandara Internasional I Gusti Ngurah Rai Bali. Kabupaten Badung Provinsi Bali.

16. PT. Angkasa Pura I (Persero). 2017. Data Penyaluran Dana Program Corporate Social Responsibility PT. Angkasa Pura I (Persero) Cabang Bandara Internasional I Gusti Ngurah Rai Bali. Kabupaten Badung Provinsi Bali.

17. Selamat, Mohamad Hisyam, Rafeah Mat Saat. 2016. Web Site Presentation of Corporate Social Responsibility towards Customers Trust and Corporate Image. International Journal of Economics and Financial Issues, 6 (7): 215-224.

18. Soemirat, Soleh \& Elvinaro Ardianto. 2007. Dasar-Dasar Public Relations. Bandung: Rosdakarya.

19. Suharno, Hadi. 2009. Manajemen Perencanaan Bandar Udara. Jakarta: PT. Raja Grafindo Persada.

20. Sukirno, Sadono. 2005. Mikro Ekonomi Teori Pengantar. Jakarta: PT. Raja Grafindo Persada

21. Peraturan Pemerintah No. 47 Tahun 2012 tentang Tanggung Jawab Sosial and Lingkungan Perseroan Terbatas.

22. Peraturan Menteri Negara Badan Usaha Milik Negara Nomor PER-09/MBU/07/2015 tentang Program Kemitraan and Program Bina Lingkungan Badan Usaha Milik Negara.

23. Undang-Undang No. 40 Tahun 2007 tentang Perseroan Terbatas.

24. Undang-Undang No. 1 Tahun 2009 tentang Penerbangan. 